\title{
Genetic polymorphisms and protein expression of P53 and BRCA1 in preneoplastic and neoplastic rat mammary glands
}

\author{
WAFA AL-DHAHERI $^{1-3^{*}}$, IMAM HASSOUNA ${ }^{2,4^{*}}$ and SHERIF M. KARAM ${ }^{1}$ \\ ${ }^{1}$ Department of Anatomy, College of Medicine and Health Sciences, and \\ ${ }^{2}$ Department of Biology, College of Science, UAE University, Al-Ain, United Arab Emirates
}

Received July 18, 2017; Accepted December 27, 2017

DOI: 10.3892/or.2018.6284

\begin{abstract}
Breast cancer is the most common type of cancer and the leading cause of cancer-related deaths among women in the United Arab Emirates and worldwide. Although many factors contribute to the high incidence of breast cancer, a considerable number of cases are related to environmental factors. In the present study, breast cancer was induced in female rats using a single dose, $80 \mathrm{mg} / \mathrm{kg}$ body $\mathrm{wt}$, of the environmental carcinogen 7,12-dimethylbenz[a]anthracene (DMBA). The aim of the present study, was to characterize some of the molecular changes that occur during breast cancer development in the DMBA-treated rat model. Mammary gland tissues of control and DMBA-treated rats were processed for: i) immunohistochemical probing using anti-BRCA1 antibody to characterize and correlate the localization of this cell cycle protein during progression to cancer, ii) western blotting to analyze the alteration of p53 protein expression in preneoplastic and neoplastic lesions of the mammary glands, and iii) polymerase chain reactions using primers specific for BRCA1 and P53 genes followed by single stranded conformational polymorphism (SSCP) or restriction fragment length polymorphism (RFLP) assays to detect possible mutations in these genes during development of breast cancer. Microscopic examination revealed a wide range of preneoplastic and neoplastic lesions providing a sequence representing the multistep process of breast cancer formation in DMBA-treated rats.
\end{abstract}

Correspondence to: Professor Sherif M. Karam, Department of Anatomy, College of Medicine and Health Sciences, UAE University, P.O. Box 17666, Al-Ain, United Arab Emirates

E-mail: skaram@uaeu.ac.ae

Present addresses: ${ }^{3}$ Communicable Diseases Department, Health Authority of Abu Dhabi, Al-Ain, United Arab Emirates; ${ }^{4}$ Physiology Unit, Zoology Department, Faculty of Science, Menoufia University, Shebin Elkom, Egypt

*Contributed equally

Key words: breast cancer, carcinogenesis, P53, BRCA1, 7,12-dimethylbenz[a]anthracene
Probing for BRCA1 protein revealed a gradual defect in its translocation from the cytoplasm to the nucleus during breast cancer progression. In control rats, BRCA1 was present in the nuclei of terminal duct epithelial cells. However, in the preneoplastic lesions, BRCA1 was localized in both the cytoplasm and nuclei of the epithelial duct cells. In all malignant lesions, BRCA1 was mostly found in the cytoplasm. Western blotting revealed initial downregulation in the expression of $\mathrm{p} 53$ protein during breast cancer development. However, with progression towards malignancy, upregulation of p53 was observed. These changes were associated with polymorphism in p53 gene, which was detected in exon 5 using SSCP assay. However, using RFLP and BamHI to digest the PCR products of exon 11 of BRCA1 gene revealed no detectable polymorphisms. In conclusion, molecular characterization of the early changes that occur during development of breast cancer provides some clues for better understanding of its pathogenesis.

\section{Introduction}

Breast cancer has been increasing in incidence and remains the most frequent and the deadliest cancer in women worldwide (1). Many factors contribute to the development of breast cancer such as age, life style and genetic factors (2). However, in many cases there is no obvious predisposing factor, supporting the view that a variety of environmental carcinogens may play a major role in the initiation of breast cancer (3). Polycyclic aromatic hydrocarbons, such as 7,12-dimethylbenz[a]anthracene (DMBA), are genotoxic environmental pollutants which have been implicated in the development of cancer and widely used in experimental models of breast cancer (4).

While research efforts have mostly focused on the advanced stages of DMBA-induced mammary gland tumors (5), little is known about the early preneoplastic changes. In 2008, when the macroscopically normal looking mammary glands of DMBA-treated rats were analyzed, they demonstrated a wide range of histopathological and cellular changes. They varied from increased signs of cell death to hyperplasia, dysplasia and in situ carcinoma. The stage of cell death was found to occur earlier than hyperplasia, and was taken to be the first stage in the multistep process of breast cancer development in DMBA-treated rats (6). These basic cellular dynamic events leading to cancer are probably associated with the acquisition of molecular alterations involving several cancer-driven 
genes (7). Identification of these alterations can thus improve our understanding of carcinogenesis and help in the development of new diagnostic tools and therapeutic modalities.

Tumor suppressor genes, such as P53 and BRCA, are frequently involved in the development of breast cancer (8). While the wild-type p53 protein suppresses cell growth, its mutated form acts as an oncogene. Mutations in the P53 gene usually result in stabilization and accumulation of its translated protein which is a frequent feature of many malignant tumors (9). It has been estimated that up to $58 \%$ of breast cancer patients have mutated P53 gene with accumulation of altered p53 protein as detected by immunological assays (10). Mutant forms of p53 protein lose the ability to bind DNA and cause abnormal cell growth (11).

BRCA1 protein interacts with many nuclear proteins, such as Rad51 and BRCA2 (12), and consequently plays several critical functions in the cell (13). BRCA1 amino terminal ring finger domain is involved in repression of estrogen receptor- $\alpha$ signaling, modulation of DNA repair, and apoptosis. The carboxyl terminal acidic domain of BRCA1 acts as a transcriptional activator when linked to DNA binding domain. Moreover, BRCA1 plays a role in the regulation of cell cycle checkpoints and centromeres (13).

Individuals carrying mutations in the BRCA1 gene have an increased risk of developing breast and ovarian tumors (14). Mutations in BRCA1 alone account for $\sim 45 \%$ of families with high incidence of breast cancer and up to $80 \%$ of families with both breast and ovarian cancer $(15,16)$. It has been shown that BRCA1 knockout mice are hypersensitive to $\gamma$-irradiation which induces chromosomal aberrations (17). Therefore, loss of transcriptional activation by BRCA1 is an important factor in oncogenesis (18). BRCA1 is also involved in the development of sporadic breast cancer by loss of heterozygosity, downregulation of mRNA expression, and methylation of the promoter region (19).

In the present study, preneoplastic and neoplastic mammary gland tissues of DMBA-treated rats were processed for protein expression and mutation analyses of P53 and BRCA1 genes. The data provide new information on this commonly used animal model of breast cancer.

\section{Materials and methods}

Animals and study design. Female virgin Wistar rats (43-50 days old) were supplied by the animal facility of the College of Medicine and Health Sciences, UAE University. The protocol described below was approved by the Animal Research Ethics Committee of the College of Medicine and Health Sciences, UAE University. All rats were kept in standard conditions with 12:12 light-dark regimen and ad libitum access to food and water.

Rats were divided into two groups. The first group included 21 rats and used for breast cancer induction using a single gavage of DMBA solution containing $80 \mathrm{mg} / \mathrm{kg}$ body weight (5). The second group included 9 rats which received only vehicle (corn oil) to serve as age-matched control. Thus, each 2 or 3 DMBA-induced rats had a control littermate.

Mammary glands of all rats were gently palpated every other day to detect development of any abnormal mass. After $15,25,30,35$ or 40 weeks of DMBA or corn oil gavage, rats in each group were sacrificed by an overdose of anesthetic. For each rat, the mammary glands of one side were dissected along with their covering skin and immediately fixed for 12-24 $\mathrm{h}$ in Bouin's solution and processed for immunohistochemistry. The opposite group of mammary glands were immediately dissected and stored at $-80^{\circ} \mathrm{C}$ for protein and DNA analysis. In case that a mammary gland had a mass or tumor, it was weighed and divided for immunohistochemistry and protein/DNA analyses.

Immunohistochemical studies. Bouin's fixed tissues were dehydrated in graded ethanol, cleared in xylene, and finally infiltrated and embedded in paraffin. Tissue blocks were cut at $5 \mu \mathrm{m}$ thickness. Tissues were deparaffinized, rehydrated, and washed in phosphate-buffered saline (PBS). Endogenous peroxidase activity was inhibited by incubating the tissue sections in methanol containing $1 \%$ hydrogen peroxide for $30 \mathrm{~min}$. The slides were placed horizontally in a humid chamber. To ensure equal conditions for all tissue sections, slides were drained off, area around sections were wiped dry, and circled with a thin film using PAP-pen (DakoCytomation, Glostrup, Denmark). Non-specific binding was blocked by incubating sections in PBS containing $1 \%$ bovine serum albumin for $45 \mathrm{~min}$. Then, sections were incubated overnight with rabbit polyclonal anti-BRCA1 antibody, clone I-20 (Santa Cruz Biotechnology Inc., Dallas, TX, USA) at $4^{\circ} \mathrm{C}$. This antibody is specific for the C-terminal region between codons 1823-1842. The catalyzed signal amplification CSA kit (DakoCytomation) was used according to the manufacturer's instructions. Tissue sections were counterstained with Harris hematoxylin.

For quantification, two different approaches were used. First, semi-quantitatively using the 100x objective of the light microscope, the overall amount of cells with labeled nuclei and those with labeled cytoplasm were estimated and scored as low $( \pm)$, medium $(+)$, high $(++)$, and very high $(+++)$ expression. The score of low characterized the moderate staining of widely scattered cells. Medium was defined by focal moderate staining in less than half of the cells. High was indicated by focal moderate staining of more than half of the cells. Very high was characterized by dark staining of more than half of the cells. Second, quantitatively, light micrographs prepared using the 100x objective lens were examined to determine the percentage of labeled cells in glandular profiles and localization of the BRCA1 protein (nuclear or cytoplasmic). Only cells with visible nuclei in the micrographs were considered. The means of labeled cells were compared in control and DMBAtreated rats using the ANOVA with post hoc Tukey test and GraphPad Prism Software (GraphPad Inc., San Diego, CA, USA).

Sodium dodecyl sulfate polyacrylamide gel electrophoresis (SDS-PAGE) and western blot analysis. Frozen mammary gland tissues of control and DMBA-treated rats were homogenized under liquid nitrogen temperature and then lysed with $1 \mathrm{ml}$ buffer containing: $100 \mathrm{mM}$ 4-(2-hydroxyethyl)1-piperazineethanesulfonic acid, $10 \%$ sucrose, $10 \mathrm{mM}$ 1,4-dithio-DL-threitol, 0.1\% 3-[(3-cholamidopropyl)dimethylammoniol]-1-propanesulfonate, $150 \mathrm{mM} \mathrm{NaCl}$, and protein inhibitors: $100 \mathrm{mM}$ phenylmethylsulfonyl fluoride, $0.1 \%$ 
Table I. The primers used in PCR reactions.

\begin{tabular}{|c|c|c|c|}
\hline \multirow{2}{*}{$\frac{\text { Primers }}{\text { BRCA1/E11 }}$} & \multicolumn{2}{|r|}{ Sequences } & Annealing temperature $\left({ }^{\circ} \mathrm{C}\right)$ \\
\hline & Forward & 5'-TTTCACCCATACACATTTG-3' & \\
\hline & Reverse & 5'-CCTTTGCCAATATTACCTG-3' & 48 \\
\hline \multirow[t]{2}{*}{ P53/E5 } & Forward & 5'-GACCTTTGATTCTTTCTCCTCTCC-3' & \\
\hline & Reverse & 5'-GGGAGACCCTGGACAACCAG-3' & 64 \\
\hline \multirow{2}{*}{ P53/E6-7 } & Forward & 5'-CTGGTTGTCCAGGGTTCTCC-3' & \\
\hline & Reverse & 5'-CCCAACCTGGCACACAGCTT-3' & 64 \\
\hline \multirow[t]{2}{*}{ P53/E8-9 } & Forward & 5'-CTTACTGCCTTGTGCTGTGC-3' & \\
\hline & Reverse & 5'-CTTAAGGGTGAAATATTCTCC-3' & 58 \\
\hline \multirow[t]{2}{*}{ P53/E10 } & Forward & 5'-GTACTGTGAATATACTTACTTCTCC-3' & \\
\hline & Reverse & 5'-GGGCTGAGGTCACTCACC-3' & 60 \\
\hline
\end{tabular}

leupeptin and aprotenin. Tissue lysates were centrifuged at $14,000 \mathrm{rpm}$ for $30 \mathrm{~min}$ at $4^{\circ} \mathrm{C}$. Protein concentrations in the supernatants were determined using the Bio-Rad protein assay kit (Bio-Rad Laboratories, Hercules, CA, USA). Equal amounts of protein $(30 \mu \mathrm{g})$ from each sample were mixed with 5X sample buffer containing Tris- $\mathrm{HCl}(\mathrm{pH} \mathrm{6.8),} \mathrm{10 \%}$ glycerol, 2\% sodium dodecyl sulfate, 2-mercaptoethanol, and bromophenol blue. Samples were boiled for $5 \mathrm{~min}$ and electrophoresed on $8 \%$ polyacrylamide gel at 80 volts for $2 \mathrm{~h}$. To check the expected size of the protein, Bio-Rad prestained protein marker was used.

After electrophoresis, proteins in the gels were transferred onto nitrocellulose membrane. Non-specific binding was blocked by PBS containing 5\% non-fat dry milk and $0.1 \%$ Tween-20 for $1 \mathrm{~h}$. Following two washes in PBS-Tween, blots were incubated overnight with anti-p53 antibody (clone PAb240; dilution 1:1,000; DakoCytomation) at $4^{\circ} \mathrm{C}$. Blots were washed with PBS-Tween, and then incubated with horseradish peroxidase-conjugated goat anti-mouse immunoglobulin (Ig) G (Cell Signaling Technology, Danvers, MA, USA) at dilution 1:1,000 for $2 \mathrm{~h}$ at room temperature. Blots were then washed with PBS-Tween and immunoreactive proteins in the blot were detected using enhanced chemiluminescence reagents (Pierce Biotechnology, Rockford, IL, USA) on X-ray film (Fuji Medical, Japan). To confirm equal loading of proteins, the same blot was immunoprobed with rabbit polyclonal antiactin antibody (dilution 1:1,000; clone AC40; Sigma, St. Louis, MI, USA). Films were scanned using BioDocAnalyze system (Biometra, Göttingen, Germany) to estimate the intensity of the bands. The percent change in protein band intensity as compared to control samples was determined.

DNA extraction. Genomic DNA was obtained from mammary glands of control and DMBA-treated rats using DNA extraction kit (Qiagen, Toronto, Canada). Tissues were quickly washed in cold PBS, weighed, and then homogenized in a mortar at liquid nitrogen temperature. The fine powder was mixed with cold PBS (100 $\mu$ l PBS per $20 \mathrm{mg}$ tissue powder). Homogenized tissue was mixed with equal amount of digestion buffer provided by the kit. QIAamp column containing DNA was transferred to clean Eppendorf tube and $50 \mu$ l elution buffer was added. The extracted DNA was stored at $-20^{\circ} \mathrm{C}$ until used. DNA concentration was determined by measuring the optical density at $260 \mathrm{~nm}$ using spectrophotometer (WPA; Cambridge, UK).

Polymerase chain reaction. PCR was performed using PuReTaq Ready-to-Go PCR beads (Amersham Pharmacia Biotech, Uppsala, Sweden). The procedure was carried out according to the manufacturer's instructions. Primers of P53 gene were obtained from Pharmacia (Piscataway, NJ, USA). BRCA1 primers were obtained from Operon Biotechnologies (Sweden). Sequences of all primers used are listed in Table I.

The PCR amplifications of P53 exons were performed using the Techne Genius PCR thermal cycler (Burlington, NJ, USA). Each sample was initially denatured at $95^{\circ} \mathrm{C}$ for $5 \mathrm{~min}$, and then subjected to 40 cycles, each included denaturation at $95^{\circ} \mathrm{C}$ for $1 \mathrm{~min}$, annealing for $1 \mathrm{~min}$, and then extension at $72^{\circ} \mathrm{C}$ for $1 \mathrm{~min}$. A final $5 \mathrm{~min}$ extension step was included. PCR products $(5 \mu \mathrm{l})$ were loaded into $1.5 \%$ agarose gel and run at 100 volts for $1 \mathrm{~h}$ at room temperature. To determine the expected size of PCR products, 100 base pair ladder marker (Amersham Biosciences Corp., Piscataway, NJ, USA) was used. The bands were visualized by staining the gel with ethidium bromide $(10 \mathrm{mg} / \mathrm{ml})$ and exposing it to the UV transilluminator (Life Technologies, Carlsbad, CA, USA). PCR amplification of BRCA1 exon 11 was performed with genomic DNA, $2.5 \mu 1$ of each primer at $10 \mathrm{pmol} / \mu 1$, and DEPC water was added to a total volume of $25 \mu \mathrm{l}$. The same conditions of P53 exon amplification were applied, except that the annealing temperature of BRCA1 exon 11 was adjusted to $48^{\circ} \mathrm{C}$.

Single-strand conformation polymorphism (SSCP). The p53 PCR-product $(5 \mu \mathrm{l})$ was denatured by adding $5 \mu$ l loading buffer containing formamide, xylene cyanol and bromophenol blue and incubated at $96^{\circ} \mathrm{C}$ for $10 \mathrm{~min}$. The mixture was immediately chilled on ice. Then, $10 \mu \mathrm{l}$ of the denatured PCR products were loaded onto a $10 \%$ non-denaturating polyacrylamide gel and run at 60 volts for $4 \mathrm{~h}$ at $4^{\circ} \mathrm{C}$, using Bio-Rad vertical electrophoresis. The silver staining kit (Amersham Pharmacia Biotech) was used to stain DNA bands in the polyacrylamide gels. The procedure was carried out according to 


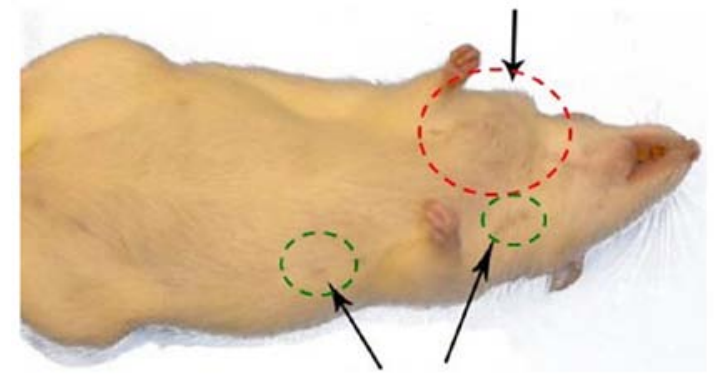

Figure 1. A rat anesthetized after 15 weeks of a single dose of DMBA. The lower arrows and green circles show mammary glands with normal size and shape. Note the tumor developed in the mammary gland of the cervical region (upper arrow and red circle).

the manufacturer's instructions. The stained polyacrylamide gels were dried using cellophane membrane (Promega, Fitchburg, WI, USA) and scanned using HP Officejet scanner and HP Image Zone software.

Restriction fragment length polymorphism (RFLP). BamHI was used to cut the PCR product of BRCA1. The enzymatic reaction included $3 \mu \mathrm{l}$ of $10 \mathrm{X}$ enzyme buffer $\mathrm{E}$ (Promega), $0.3 \mu \mathrm{l} 1 \%$ bovine serum albumin (Promega), $30 \mathrm{U} \mathrm{BamHI}$ enzyme (Promega) and $10 \mu 1$ BRCA1 PCR product. The reaction mixture was brought up to $30 \mu \mathrm{l}$ with DEPC-treated water. All samples were incubated overnight at $37^{\circ} \mathrm{C}$ in block heater (Stuart Scientific, Staffordshire, UK). The digested products were loaded in $10 \%$ polyacrylamide gel for $2 \mathrm{~h}$ at $110 \mathrm{~V}$. Gels were stained in the running TBE buffer containing ethidium bromide. Bands were finally visualized using the UV transilluminator and photographed.

\section{Results}

Gross observation of the mammary glands of DMBA-treated rats revealed tumor formation in the cervical, thoracic or abdominoinguinal regions (6). Fig. 1 shows an example of these DMBA-treated rats with a tumor in the cervical mammary gland, but all other mammary glands appeared small in size as those of the control. However, microscopic examination of all the mammary glands of DMBA-treated rats sacrificed after $15,25,30,35$ and 40 weeks revealed the development of a wide range of pathological changes. None of the mammary glands appeared microscopically normal as in the control. The changes included increased cell death, hyperplasia, dysplasia, adenoma, carcinoma in situ and invasive carcinoma (Fig. 2).
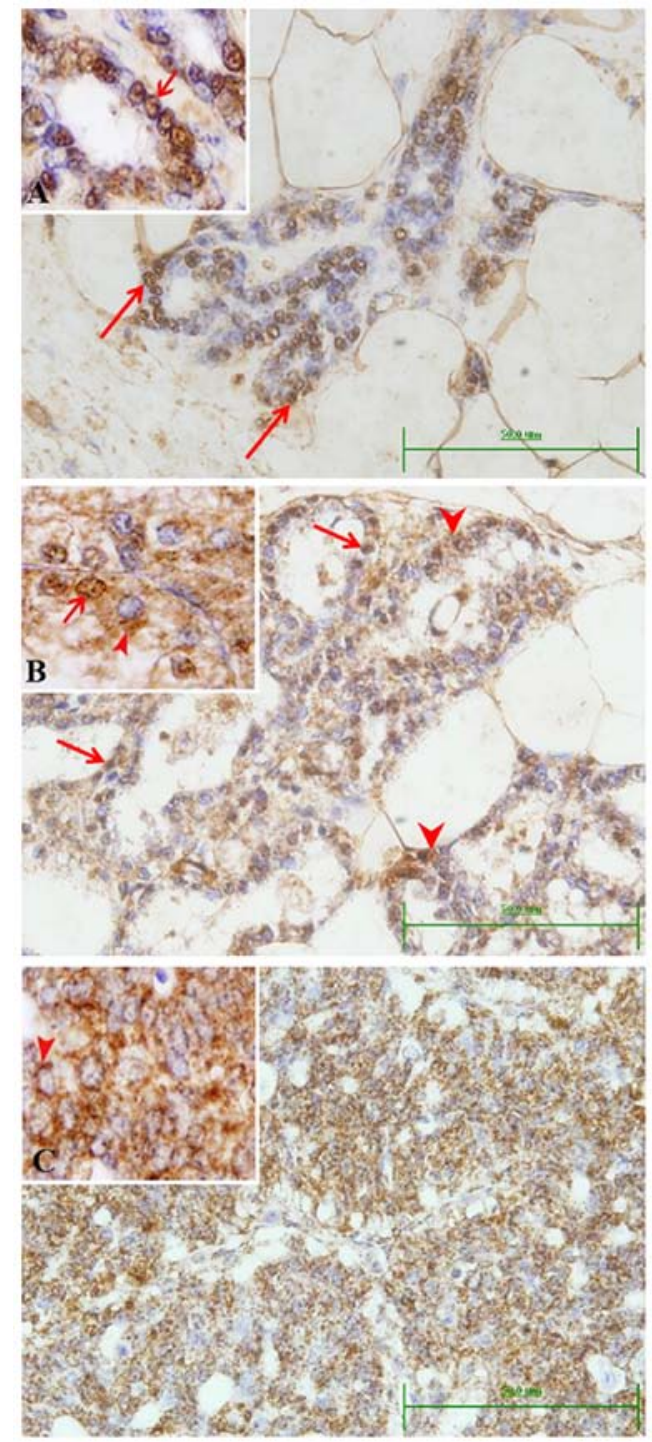

Figure 3. Immunolocalization of BRCA1 in the mammary glands of (A) control, and (B and C) DMBA-treated rats. (A) Normal mammary gland of control rat shows BRCA1 protein mainly in the nuclei of duct epithelial cells (arrows). (B) Dysplastic mammary gland shows BRCA1 in both the nucleus (arrows) and cytoplasm (arrow heads) of epithelial cells. (C) Cribriform carcinoma showing mostly cytoplasmic expression of BRCA1 (arrow heads). Scale bar, $50 \mu \mathrm{m}$ and insets are magnified twice.

These preneoplastic and neoplastic lesions were similar to those previously identified and characterized (6). In addition, mammary gland tumors were developed in $\sim 29 \%$ of the treated

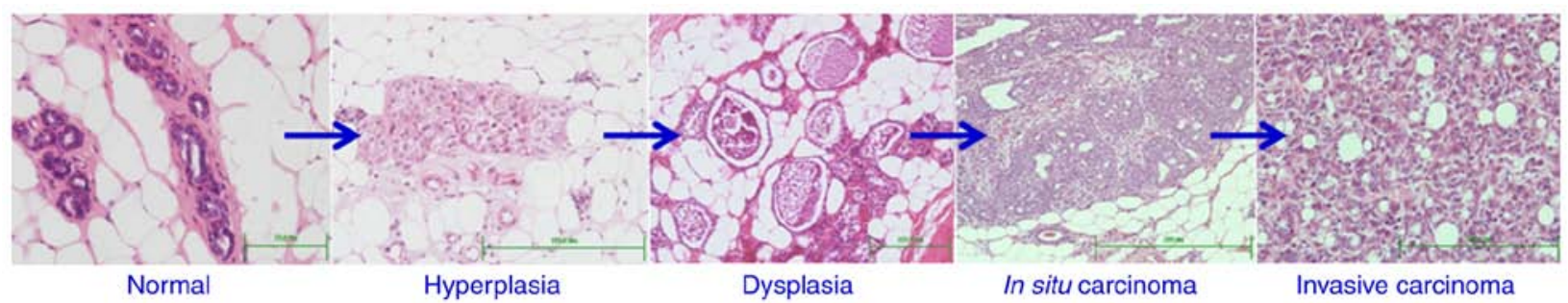

Figure 2. Light micrographs of rat mammary gland tissue sections stained with hematoxylin and eosin representing the features of control tissue as compared to DMBA-induced preneoplastic (hyperplasia and dysplasia) and neoplastic (in situ and invasive carcinomas) lesions. 
Table II. Protein expression of BRCA1 in mammary glands of control and DMBA-induced rats.

\begin{tabular}{|c|c|c|c|}
\hline \multirow[b]{2}{*}{ Weeks post DMBA } & \multirow[b]{2}{*}{ Mammary glands } & \multicolumn{2}{|c|}{ BRCA1 expression } \\
\hline & & Nucleus & Cytoplasm \\
\hline \multirow[t]{3}{*}{15} & Control & ++ & + \\
\hline & Typical hyperplasia & + & ++ \\
\hline & Cribriform carcinoma & \pm & +++ \\
\hline 25 & Typical hyperplasia & + & ++ \\
\hline \multirow[t]{2}{*}{30} & Typical hyperplasia & + & ++ \\
\hline & In situ cribriform carcinoma & \pm & ++ \\
\hline \multirow[t]{4}{*}{35} & Typical hyperplasia & + & ++ \\
\hline & In situ cribriform carcinoma & \pm & ++ \\
\hline & Lactating adenoma & ++ & ++ \\
\hline & Cribriform carcinoma & \pm & +++ \\
\hline \multirow[t]{2}{*}{40} & Typical hyperplasia & + & ++ \\
\hline & Squamous cell papilloma & + & ++ \\
\hline
\end{tabular}

DMBA, 7,12-dimethylbenz[a]anthracene.

rats. Approximately $14 \%$ of all mammary glands examined developed benign tumors and $19 \%$ were invasive or malignant.

Immunohistochemical localization of BRCA1. Control rats showed that BRCA1 protein was present mainly in the nuclei of some luminal epithelial duct cells (Fig. 3A). Faint cytoplasmic stain was also observed in cells of some small ducts, which was more apparent in the large ducts. Early microscopic lesions (hyperplasia and dysplasia) developed in DMBA-treated rats showed both nuclear and cytoplasmic localization of BRCA1 (Fig. 3B). This nucleo-cytoplasmic pattern of BRCA1 expression was also noted in some neoplastic lesions classified as lactating adenoma and squamous cell papilloma. However, in case of localized and invasive carcinomas (in situ cribriform, cribriform and papillary carcinoma), BRCA1 protein became mostly localized in the cytoplasm (Fig. 3C). Scoring of the immunolocalization of BRCA1 in rat mammary glands with different histopathological conditions are presented in Table II. It shows a change in the pattern of the expression of BRCA1 from more nuclear in control tissues to more cytoplasmic in DMBA-treated tissues. In addition, counts in tissue sections obtained from different mammary glands of control and DMBA-treated rats revealed that the percentages of cells with BRCA1 labeled nuclei gradually dropped from 69 to 54 to 12 in control, preneoplastic and neoplastic tissues, respectively. The differences between these percentages of nuclear labeling were statistically significant (Fig. 4). This change in BRCA1 nuclear labeling was associated with a significant increase in the percentages of cells with BRCA1 labeled cytoplasm from 9 to 58 to 91 in control, preneoplastic and neoplastic tissues, respectively (Fig. 4).

Expression of p53 protein. Homogenized tissue samples of the mammary glands obtained from control and DMBA-treated rats were analyzed by western blotting to study the expression of p53 protein during breast cancer progression.

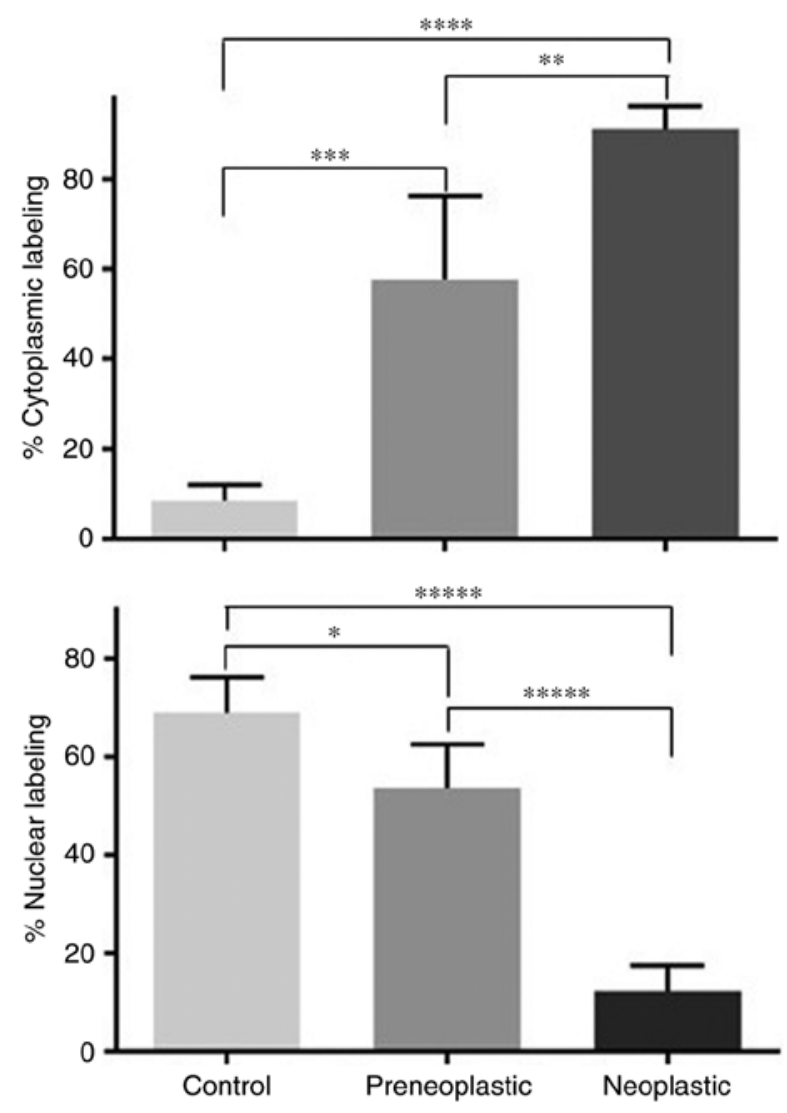

Figure 4. Percentages of epithelial cells expressing BRCA1 in the cytoplasm (upper graph) and nuclei (lower graph) of mammary gland tissues of control and DMBA-treated rats with prenoplastic and neoplastic changes. The data are expressed as mean \pm SD. The analysis of variance and Tukey's post hoc test revealed that the mean values of both nuclear and cytoplasmic labeling of the 3 groups of tissues are significantly different from each other.

Representative results of 3 different experiments are shown in Fig. 5. Comparing to control tissue (Fig. 5; lane 1), initial 

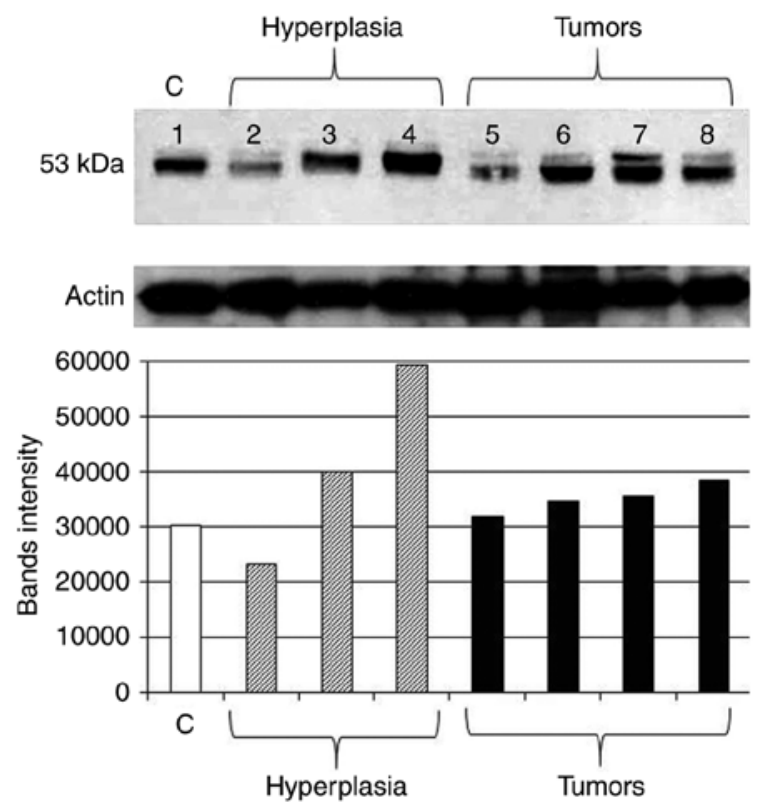

Figure 5. Immunoblot analysis showing p53 expression in mammary gland tissues obtained from control rat $(\mathrm{C}$; lane 1$)$ and DMBA-treated rats with hyperplasia (lanes 2-4) and tumors (lanes 5-8). The middle panel shows immunoblotting for the housekeeping protein, actin. The graph shows the quantification of the band intensities of p53 to actin signal.

downregulation in some hyperplastic and benign lesions was observed (Fig. 5; lanes 2 and 5, respectively). These were from mammary glands of rats treated with DMBA and sacrificed after 35 weeks. In these rats, some mammary glands progressed toward malignancy, and therefore, the amount of p53 was increased. This was either the accumulated wild-type form or the mutant form detected using anti-p53 antibody clone PAb240 (Fig. 5, lanes 3, 4 and 6-8). Measurement of band densities confirmed these expression patterns of p53 (Fig. 5). Calculations of percent change in band intensity, as compared to control, showed an increase in tissues with hyperplasia by 33 and $96 \%$ (except for a $23 \%$ decrease in one case) and an increase in all neoplastic cases by 5, 15, 18 and $27 \%$.

SSCP analysis of P53 gene in rat mammary glands. PCR products of exon 5 revealed $270 \mathrm{bp}$ amplicon for all samples when compared to the standard DNA molecular marker. SSCP analysis of this $270 \mathrm{bp}$ product of control mammary glands showed two bands as indicated in Fig. 6. Out of 9 tumors, two of them (22\%) exhibited band shift (3 extra bands) with electrophoresis in addition to the two bands appeared in control sample. These two tumors were developed in rats treated with DMBA and sacrificed after 25 and 32 weeks. In addition, some hyperplastic mammary glands showed band shifting similar to that of tumor samples as shown in Fig. 6. PCR amplification of exon 6-7 produced $300 \mathrm{bp}$ band for all samples in agarose gel. SSCP analysis displayed 3 bands representing the normal pattern of P53 exon 6-7 (Fig. 6). Analysis of DMBA-treated samples revealed bands similar to those of control with no shift detected in the polyacrylamide gels (Fig. 6). All PCR products of P53 exon 8-9 from control and treated mammary glands showed single amplicon indicated by agarose gel electrophoresis at $350 \mathrm{bp}$. The SSCP analysis of P53 exon 8-9 showed two bands similar to the pattern of exon 5. SSCP analysis of the $410 \mathrm{bp}$ fragment of exon 10 of P53 gene showed two main bands in the control and DMBA-treated mammary gland (Fig. 6).

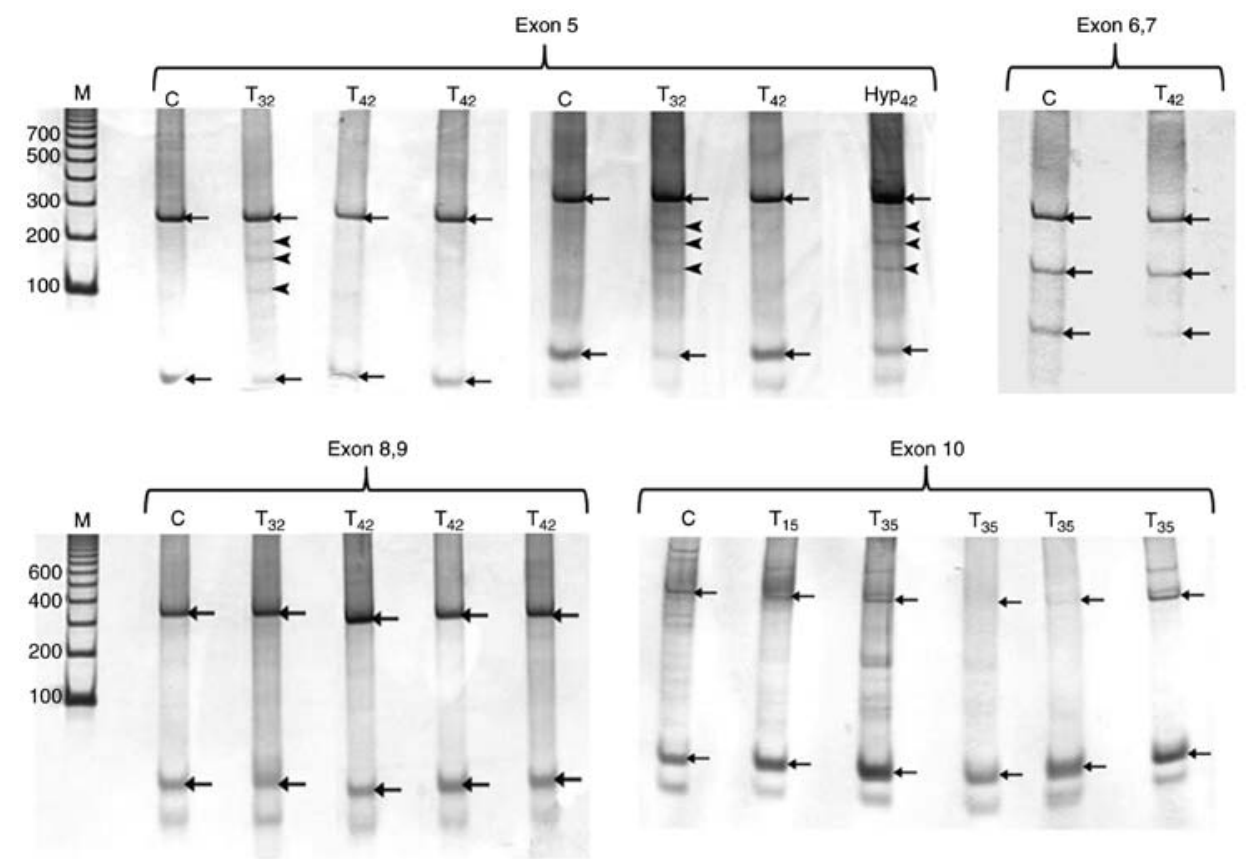

Figure 6. SSCP analysis of the PCR products of P53 in control (C), and DMBA-treated (T) rats. Exon 5, note the loss of normal banding pattern in two DMBAinduced tumors $\left(\mathrm{T}_{32}\right)$. The bands of the hyperplastic lesion $\left(\mathrm{Hyp}_{42}\right)$ of the DMBA-treated rat are similar to those of the $\mathrm{T}_{32}$. Exons 6, 7, note the PCR products of control tissue (C) and the DMBA-induced tumor $\left(\mathrm{T}_{42}\right)$. Note that there is no difference in the SSCP pattern in the control and tumor samples. Exon 8, 9, note that there is no difference in the pattern of control tissue (C) and DMBA-induced tumors obtained from different rats $\left(\mathrm{T}_{15}, \mathrm{~T}_{35}\right.$, and $\left.\mathrm{T}_{42}\right)$. Exon 10, analysis of exon 10 of normal mammary tissue of control rat $(C)$ and DMBA-induced tumors in different rats $\left(T_{15}\right.$ and $\left.T_{35}\right)$ shows no band shifting in any lane. 


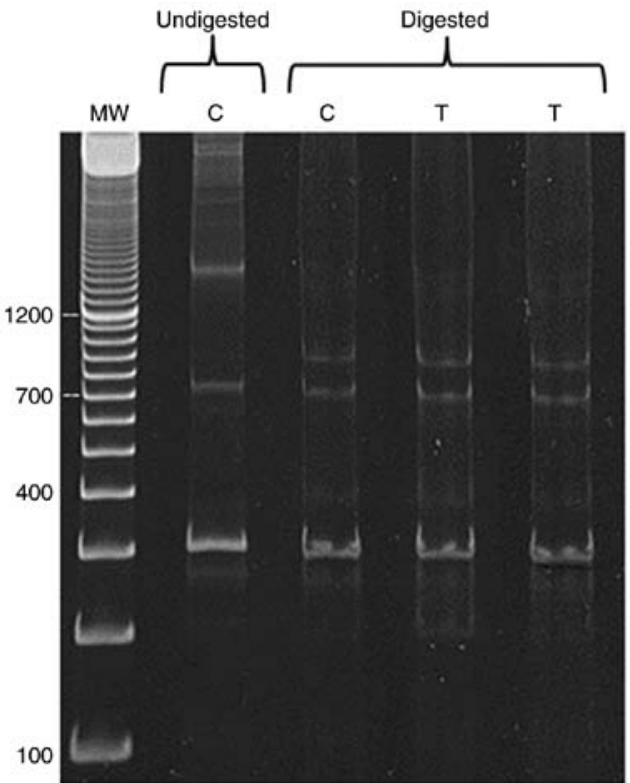

Figure 7. PCR-RFLP analysis of BRCA1 exon 11 in tumors obtained from DMBA-treated $(\mathrm{T})$ rats. Undigested band at 1,600 bp in lane $\mathrm{C}$ (from the left) represents BRCA1 target product which was digested with $\mathrm{BamHI}$ and produced two bands at 900 and 700 bp (lanes digested C and T). All samples produced the same pattern compared to digested control.

RFLP analysis of BRCA1 gene in rat mammary glands. The PCR products of exon 11 of BRCA1 gene revealed more than one band on the gel (Fig. 7, lane undigested C). Therefore, the RFLP method was used to detect polymorphism. BamHI was found to be the appropriate cutter for BRCA1 fragment. PCR product of BRCA1 exon 11 was at $1,600 \mathrm{bp}$, which was the biggest size obtained using specific primer sequence mentioned in the Material and methods section. In Fig. 7, the digested products using Bam HI showed no remarkable difference between control and tumor samples.

\section{Discussion}

The present study demonstrates that DMBA-induced preneoplastic and neoplastic lesions develop a block in the nuclear translocation of BRCA1 protein and upregulation and polymorphisms of P53 gene.

Various studies previously indicated that BRCA1 acts as a nuclear-cytoplasmic shuttle protein, and its transport is altered by DNA damage $(20,21)$. Thus, it seems that breast cancer progression is associated with the production of an inactive form of BRCA1 which cannot be targeted to the nucleus and therefore, remains in the cytoplasm of cancer cells. This could be due to impairment of nuclear localization signals and/or the nuclear export signal of BRCA1 protein (20). The data presented in the present study indicate that alterations in the localization of BRCA1 protein occur in preneoplastic lesions of the DMBA-rat model of mammary gland carcinogenesis.

P53 is a tumor-suppressor gene which has an apparent role in the development of breast cancer in humans and rodents $(22,23)$. In the present study, the expression of $\mathrm{p} 53$ protein was studied in mammary glands of DMBA-treated rats using an antibody that detects both wild-type and mutant forms of p53 (24). Using SDS-PAGE and western blot analysis, the $\mathrm{p} 53$ protein is found to be differentially expressed during mammary gland carcinogenesis. It tends to be downregulated in preneoplastic lesions, but becomes upregulated in malignant tumors. These findings correlate with previous studies in human breast cancer (25). A significant correlation between p53 mutations and p53 overexpression was reported in both canines and humans $(26,27)$. In addition, p53 protein expression in benign tumors is much less compared to that in malignant lesions (26).

Mutations in p53 gene are very common in human cancers; they occur in $20-40 \%$ of breast cancer cases (28). In addition, $50 \%$ of cancers of colon, stomach, and liver are characterized by p53 mutations (29). Most of these P53 mutations are clustered within exons 4-8, which encode a highly conserved region, containing the DNA binding domain of the protein $(29,30)$. In the present study, exons 5, 6-7, 8-9 and 10 of p53 gene were studied for possible mutations that may occur during breast cancer development. Using SSCP, it was possible to detect P53 polymorphism in some rats with hyperplastic mammary glands (Fig. 6). In humans, previous studies reported P53 mutations in individuals with preinvasive mammary gland lesions: Atypical ductal hyperplasia and ductal carcinoma in situ $(31,32)$. In mice, overexpression of p53 and its mutation in hyperplastic mammary glands was also reported (33).

It has been estimated that $33.3 \%$ of the mammary gland tumors developed in the present study acquire polymorphism in $\mathrm{P} 53$ exon 5. In the DMBA-treated rats, base substitutions at $A$ or $G$ in the sense strand of the cDNA accounted for $95 \%$ of all the point mutations of P53 gene. The predominance of purine (A or $\mathrm{G}$ ) mutations is consistent with the fact that DMBA-adduct formation preferentially occurs on $\mathrm{dA}$ and $\mathrm{dG}(34,35)$, leading to depurination (36).

There may be a concern that some models of breast cancer may not reflect the disease in humans. This is not the case for the DMBA model. It has been demonstrated that the different forms of preneoplastic and neoplastic histopathological changes of DMBA animal model are very similar to those in humans (6). Therefore, the in vivo model of DMBA-induced breast cancer is useful for understanding of disease progression and early detection in humans. In addition, the observations that BRCA1 and P53 genes are altered in DMBA breast cancer model are not surprising. They were also described in human breast cancer tissues $(8,10,19)$. However, the present study has probed some questions regarding p53 and BRCA1 proteins. In humans, it is known that hyperplastic mammary gland lesions precede tumor formation. However, the associated biochemical changes are not well characterized, at least for mammary gland lesions due to DMBA. The present study has demonstrated that alteration of BRCA1 subcellular localization and upregulation and mutations of P53 expression are common changes. Therefore, due to the similarities of the multistep process of breast cancer development in humans and rats, the limitations of DMBA model are minimal.

In conclusion, the present study demonstrates that the morphological changes in mammary gland induced by a single gavage of DMBA are associated with alterations in the expression of p53 and BRCA1 proteins. An initial downregulation followed by upregulation in the expression of p53 follows the sequence of the morphological changes. This is associated with polymorphism of exon 5 of P53 gene which is detected 
as early as during hyperplasia. While no change in the level of BRCA1 protein was detected, its translocation from the cytoplasm to nucleus is blocked during breast cancer progression. Therefore, it seems that P53 mutations in exon 5 and blocking the nuclear translocation of BRCA1 are important events for mammary gland carcinogenesis in DMBA-treated rats.

\section{Acknowledgements}

The present study was supported by funds from the UAEU and Terry Fox Foundation for Cancer Research. The kind assistance of Ms. Salma Awad with some biochemical procedures is highly appreciated.

\section{References}

1. Ferlay J, Soerjomataram I, Dikshit R, Eser S, Mathers C, Rebelo M, Parkin DM, Forman D and Bray F: Cancer incidence and mortality worldwide: Sources, methods and major patterns in GLOBOCAN 2012. Int J Cancer 136: E359-E386, 2015.

2. Dieterich M, Stubert J, Reimer T, Erickson N and Berling A: Influence of lifestyle factors on breast cancer risk. Breast Care 9: 407-414, 2014.

3. Seltenrich $\mathrm{N}$ : Institutes in the Lead: Identifying environmental factors in breast cancer. Environ Health Perspect 124 A199-A205, 2016

4. Rennó AL, Alves-Júnior MJ, Rocha RM, De Souza PC, de Souza VB, Jampietro J, Vassallo J, Hyslop S, Anhê GF, de Moraes Schenka NG, et al: Decreased expression of stem cell markers by simvastatin in 7,12-dimethylbenz(a)anthracene (DMBA)-induced breast cancer. Toxicol Pathol 43: 400-410, 2015.

5. Russo J: Significance of rat mammary tumors for human risk assessment. Toxicol Pathol 43: 145-170, 2015.

6. Al-Dhaheri WS, Hassouna I, Al-Salam S and Karam SM: Characterization of breast cancer progression in the rat. Ann NY Acad Sci 1138: 121-131, 2008.

7. Ciriello G, Miller ML, Aksoy BA, Senbabaoglu Y, Schultz N and Sander C: Emerging landscape of oncogenic signatures across human cancers. Nat Genet 45: 1127-1133, 2013

8. Peng L, Xu T, Long T and Zuo H: Association between BRCA status and P53 status in breast cancer: A meta-analysis. Med Sci Monit 22: 1939-1945, 2016.

9. Rivlin N, Brosh R, Oren M and Rotter V: Mutations in the p53 tumor suppressor gene: Important milestones at the various steps of tumorigenesis. Genes Cancer 2: 466-474, 2011.

10. Elledge RM and Allred DC: The P53 tumor suppressor gene in breast cancer. Breast Cancer Res Treat 32: 39-47, 1994.

11. Maslon MM and Hupp TR: Drug discovery and mutant p53. Trends Cell Biol 20: 542-555, 2010.

12. Jiang Q and Greenberg RA: Deciphering the BRCA1 tumor suppressor network. J Biol Chem 290: 17724-17732, 2015.

13. Rosen EM, Fan S, Pestell RG and Goldberg ID: BRCA1 gene in breast cancer. J Cell Physiol 196: 19-41, 2003.

14. Miki Y, Swensen J, Shattuck-Eidens D, Futreal PA, Harshman K, Tavtigian S, Liu Q, Cochran C, Bennett LM, Ding W, et al: A strong candidate for the breast and ovarian cancer susceptibility gene BRCA1. Science 266: 66-71, 1994.

15. Easton DF, Bishop DT, Ford D and Crockford GP: Genetic linkage analysis in familial breast and ovarian cancer: Results from 214 families. The breast cancer linkage consortium. Am J Hum Genet 52: 678-701, 1993.

16. Keshavarzi F, Javadi GR and Zeinali S: BRCA1 and BRCA2 germline mutations in 85 Iranian breast cancer patients. Fam Cancer 11: 57-67, 2011

17. Shen SX, Weaver Z, Xu X, Li C, Weinstein M, Chen L, Guan XY, Ried T and Deng CX: A targeted disruption of the murine Brcal gene causes gamma-irradiation hypersensitivity and genetic instability. Oncogene 17: 3115-3124, 1998.
18. Ottini L, D'Amico C, Noviello C, Lauro S, Lalle M, Fornarini G, Colantuoni OA, Pizzi C, Cortesi E, Carlini S, et al: BRCAl and $B R C A 2$ mutations in central and southern Italian patients. Breast Cancer Res 2: 307-310, 2000.

19. Fraser JA, Reeves JR, Stanton PD, Black DM, Going JJ, Cooke TG and Bartlett JM: A role for BRCA1 in sporadic breast cancer. Br J Cancer 88: 1263-1270, 2003.

20. Feng Z, Kachnic L, Zhang J, Powell SN and Xia F: DNA damage induces p53-dependent BRCA1 nuclear export. J Biol Chem 279: 28574-28584, 2004.

21. Yang ES and Xia F: BRCA1 16 years later: DNA damage-induced BRCA1 shuttling. FEBS J 277: 3079-3085, 2010.

22. Hollstein M, Sidransky D, Vogelstein B and Harris CC: p53 mutation in human cancers. Science 253: 49-53, 1991.

23. Zurer I, Hofseth LJ, Cohen Y, Xu-Welliver M, Hussain SP, Harris CC and Rotter V: The role of p53 in base excision repair following genotoxic stress. Carcinogenesis 25: 11-19, 2004.

24. Gannon JV, Greaves R, Iggo R and Lane DP: Activating mutation in $\mathrm{p} 53$ produce a common conformational effect. A monoclonal antibody specific for the mutant form. EMBO J 9: 1595-1602, 1990.

25. Andersen TI, Holm R, Nesland JM, Heimdal KR, Ottestad L and Børresen AL: Prognostic significance of TP53 alterations in breast carcinoma. Br J Cancer 68: 540-548, 1993.

26. Lee CH, Kim WH, Lim JH, Kang MS, Kim DY and Kweon OK: Mutation and overexpression of p53 as a prognostic factor in canine mammary tumors. J Vet Sci 5: 63-69, 2004.

27. Rossner P Jr, Gammon MD, Zhang YJ, Terry MB, Hibshoosh $\mathrm{H}$, Memeo L, Mansukhani M, Long CM, Garbowski G, Agrawal M, et al: Mutations in $p 53, \mathrm{p} 53$ protein overexpression and breast cancer survival. J Cell Mol Med 13: 3847-3857, 2009.

28. Kalemi TG, Lambropoulos AF, Gueorguiev M, Chrisafi S, Papazisis KT and Kotsis A: The association of p53 mutations and p53 codon 72, Her 2 codon 655 and MTHFR C677T polymorphisms with breast cancer in Northern Greece. Cancer Lett 222: 57-65, 2004.

29. Jerry DJ, Kittrell FS, Kuperwasser C, Laucirica R, Dickinson ES, Bonilla PJ, Butel JS and Medina DA: Mammary-specific model demonstrates the role of the p53 tumor suppressor gene in tumor development. Oncogene 19: 1052-1058, 2000.

30. Malisic E, Jankovic R, Slavkovic D, Milovic-Kovacevic M and Radulovic S: P53 gene mutations and codon 72 polymorphism in ovarian carcinoma patients from Serbia. J BUON 15: 101-106, 2010.

31. Keohavong P, Gao WM, Mady HH, Kanbour-Shakir A and Melhem MF: Analysis of p53 mutations in cells taken from paraffin-embedded tissue sections of ductal carcinoma in situ and atypical ductal hyperplasia of the breast. Cancer Lett 212: 121-130, 2004.

32. ZhouW,Muggerud AA, Vu P,DueEU,Sørlie T,Børresen-Dale AL, Wärnberg F and Langerød A: Full sequencing of TP53 identifies identical mutations within in situ and invasive components in breast cancer suggesting clonal evolution. Mol Oncol 3: 214-219, 2009.

33. Jerry DJ, Ozbun MA, Kittrell FS, Lane DP, Medina D and Butel JS: Mutations in p53 are frequent in the preneolpastic stage of mouse mammary tumor development. Cancer Res 53: 33743381,1993

34. Manjanatha MG, Chen JB, Shaddock JG Jr, Harris AJ, Shelton SD and Casciano DA: Molecular analysis of lacI mutations in Rat ${ }^{\mathrm{TM}}$ cells exposed to 7,12-dimethylbenz[a]anthracene: Evidence for DNA sequence and DNA strand biases for mutation. Mutat Res 372: 53-64, 1996.

35. Chatterjee $M$, Janarthan M, Manivannan R, Rana A and Chatterjee M: Combinatorial effect of fish oil (Maxepa) and $1 \alpha, 25$-dihydroxyvitamin $\mathrm{D}_{3}$ in the chemoprevention of DMBA-induced mammary carcinogenesis in rats. Chem Biol Interact 188: 102-110, 2010.

36. Chakravarti D, Pelling JC, Cavalieri EL and Rogan EG: Relating aromatic hydrocarbon-induced DNA adducts and c-H-ras mutations in mouse skin papillomas: The role of apurinic sites. Proc Natl Acad Sci USA 92: 10422-10426, 1995. 